\title{
AN EXPERT SYSTEM FOR DETECTION OF DIABETES MELLITUS WITH FORWARD CHAINING METHOD
}

\author{
Tati Mardiana' ${ }^{1}$, Ega Maulana Ditama², Tuslaela $^{3}$ \\ ${ }^{1}$ Information System \\ Universitas Bina Sarana Informatika \\ 1tati.ttm@bsi.ac.id \\ 2,3Information System \\ STMIK Nusa Mandiri \\ 2maulana26cc@gmail.com; ${ }^{3}$ tuslaela.tll@nusamandiri.ac.id
}

\begin{abstract}
In recent years, the diabetes mellitus in Indonesia has become a health problem in the community because its population has increased 2-3 times faster than other countries. Diabetes prevalence in Indonesia ranks 4th highest in the world after China, India and the United States. People can prevent complications and premature death if they detect early symptoms of diabetes. However, people do not know that they are at risk of diabetes, not had knowledge about the symptoms of diabetes, complexity of the process diagnosis and the high cost of examinations. Therefore, we need an application that can provide the results of the type of diabetes and its management solutions as practiced by experts. The aim of this research is to develop an expert system for detection types of diabetes such as: type one diabetes, type two diabetes, neuropathy diabetes, diabetes retinopathy, and diabetes nephropathy. The object of this research is diabetes carried out in March to April 2019 in the Klinik Pratama Desa Putera. This study uses primary data from patients who had a history of diabetes at Klinik Pratama Desa Putra and secondary data in the form of literature, research journals, and data documents needed to compile this study. In addition, we generated a knowledge base using forward chaining. The test results show that the expert system meets the functional requirements and the system performance reaches an accuracy of $100 \%$. This expert system helps people in Indonesia to detect diabetes early so that it can prevent complications.
\end{abstract}

Keywords: Diabetes Mellitus, Detection, Forward Chaining, An Expert Systems, Health.

\begin{abstract}
Abstrak
Dalam beberapa tahun terakhir, diabetes mellitus di Indonesia telah menjadi masalah kesehatan di masyarakat karena populasinya telah meningkat 2-3 kali lebih cepat dari negara lain. Prevalensi diabetes di Indonesia menempati urutan ke-4 tertinggi di dunia setelah Cina, India dan Amerika Serikat. Seseorang dapat mencegah komplikasi dan kematian dini jika mereka mendeteksi gejala awal diabetes. Namun, mereka tidak mengetahui jika dirinya beresiko diabetes karena tidak memiliki pengetahuan tentang gejala diabetes, proses diagnosis yang kompleks dan tingginya biaya pemeriksaan. Oleh karena itu, diperlukan suatu aplikasi yang dapat memberikan hasil tipe penyakit diabetes serta solusi penatalaksanaannya seperti yang dilakukan oleh para ahli. Tujuan dari penelitian ini adalah untuk mengembangkan sistem pakar untuk deteksi tipe penyakit diabetes seperti: diabetes tipe satu, diabetes tipe dua, diabetes neuropati, diabetes retinopati, dan diabetes nefropati. Objek penelitian ini adalah penyakit diabetes yang dilakukan pada bulan Maret hingga April 2019 di Klinik Pratama Desa Putera. Penelitian ini menggunakan data primer dari pasien yang memiliki riwayat diabetes di Klinik Pratama Desa Putra dan data sekunder dalam bentuk literatur, jurnal penelitian, dan dokumen data yang diperlukan untuk menyusun penelitian ini. Selain itu, kami menghasilkan basis pengetahuan menggunakan forward chaining. Hasil pengujian menunjukkan bahwa sistem pakar memenuhi persyaratan fungsional dan kinerja sistem mencapai akurasi 100\%. Sistem pakar ini membantu masyarakat di Indonesia untuk mendeteksi penyakit diabetes sejak dini untuk mencegah komplikasi.
\end{abstract}

Kata kunci: Diabetes Mellitus, Deteksi, Forward Chaining, Sistem Pakar, Kesehatan. 


\section{INTRODUCTION}

Diabetes mellitus triggered the biggest health crisis in the 21st century. The number of people with diabetes mellitus in the world based on data from the International Diabetes Federation in 2014 as many as 384 million people increased $5.74 \%$ from 2011 as many as 366 million people and researchers estimate will increase to 592 million people in 2003. Currently, diabetes mellitus in Indonesia has become a health problem in the community because its population is increasing 2-3 times faster than other countries. The prevalence of Indonesian diabetics ranks 4 th highest in the world after China, India and the United States (Harum et al., 2013). The number of people with diabetes mellitus in Indonesia based on Basic Health Research data (RisKesDas) in 2013 there were 10 million people and 17.9 million people who are at risk of suffering from diabetes mellitus (Erawantini et al., 2019). The public must be aware of diabetes mellitus as a silent killer. Ordinarily someone knows suffering from diabetes mellitus after experiencing various chronic complications such as kidney, heart disease, blindness, and nerve disorders (Inayati \& Qoriani, 2016). The number of deaths due to diabetes mellitus in 2014 was 4.9 million with 1 death every seven seconds in the world (Zubaedah, 2017). Diabetes mellitus and its complications bring huge economic losses for people with diabetes mellitus and their families, the national health and economic system through direct medical costs, job loss and income (Ministry of Cooperatives Small and Medium Enterprises, 2015). A person can prevent complications and premature death by detecting the symptoms of diabetes early on and making comprehensive management in the form of weight loss, administration of antidiabetic drugs and lifestyle changes (Raditiya \& Aditya, 2016). However, the public does not know about the potential for diabetes due to lack of knowledge about the symptoms of diabetes, the complexity of the diagnosis process and the high cost of examination (Andriyanto \& Santoso, 2017). Therefore, we need an application that is able to detect diabetes as practiced by experts. The development of artificial intelligence technology is developing very rapidly. Currently the medical field is using artificial intelligence technology to solve specific problems (Riadi, 2017) in the form of expert systems (Niswati et al., 2016). There are several studies that apply expert systems as a solution in the detection of diabetes such as Ginting and Novriyeni build an expert system for the detection of diabetes with the method of foward chaining (Ginting \& Novriyeni, 2012), Inayati and Qoriani propose an expert system for diagnosing diabetes mellitus with an android-based android the calculation process uses the inference method with classical probability (Inayati \& Qoriani, 2016), Niswati, et al., built the fuzzy logic application in diagnosing diabetes mellitus (Niswati et al., 2016), Riadi applied the certainty factor method for the expert system of diagnosing diabetes mellitus (Riadi, 2017), and Andriyanto and Santoso built an expert system modeling to determine diabetes mellitus using the naive bayes method (Andriyanto \& Santoso, 2017). Based on previous research, the aim of this study is to produce an expert system to detect type one diabetes, type two diabetes, diabetes neuropathy, diabetic retinopathy, and diabetic nephropathy using the forward chaining method. The application of this expert system can help people in Indonesia to know diabetes early to prevent complications.

\section{RESEARCH METHOD}

In accordance with the previous problem, this type of research is descriptive research. The object of this research is diabetes carried out in March to April 2019 at the Pratama Clinic of Putera Village. This study began with observations on diabetic patients. Based on observations and interviews, diabetic patients who seek treatment at Pratama Desa Putra Clinic know they have diabetes after complications. Usually people with diabetes do not check the symptoms of diabetes to the clinic because the examination process is complex and expensive. This study uses primary data and secondary data. Directly, we obtained primary data from patients who had a history of diabetes at Pratama Desa Putra Clinic and secondary data in the form of literature, research journals, and document data needed to compile this study. The instrument in this study uses guidelines for direct observation and interviews. Data collection techniques in this study were observation by going directly to clinics and hospitals, and observing patients, situations, and conditions in place regarding diabetes mellitus (DM), in-depth interviews with Dr. Feriadi Suwarna, Sp.PD, dr. Khaira Utia Yusrie, Sp.PD, and Dr. Pius Haris Aryanto, MM and literature studied by collecting and studying literature, journals, and supporting documents related to the problem of diabetes mellitus. Based on the data collected, we conduct an analysis to form a knowledge base which is a representation of an expert consisting of facts in the form of information about objects using 
the Forward Chaining method. In this process, we check each rule to see whether the data being observed will meet the premise of that rule. Furthermore, based on an expert knowledge base, we built an expert system using the waterfall method, covering the analysis, design, implementation and testing stages.

\section{RESEARCH RESULTS AND DISCUSSION}

\section{Software Requirements Analysis}

An expert system for diabetes mellitus detection is a web-based application where patients can see, search and detect diabetes mellitus that occurs in a person by referring to the symptoms experienced and getting information about the factors and their solutions. Based on adequate knowledge representation from experts in internal and general medicine as presented in table 1 and figure 1, we developed an expert system to detect diabetes such as Diabetes Type One (P1), Diabetics Neuropathy (P2), Diabetics Retinopathy (P3), Nephropathy Diabetes (P4), and Type Two Diabetes (P5).

Table 1 Expert Table

\begin{tabular}{|c|c|c|c|c|c|c|}
\hline Code & Symptoms Name & P1 & P2 & P3 & P4 & P5 \\
\hline G01 & Age less than 30 years & $*$ & $*$ & $*$ & $*$ & \\
\hline G02 & Eat a lot without gaining weight & $*$ & & & & \\
\hline G03 & Cramps often occur & $*$ & & & & \\
\hline G04 & Concentration is easily disturbed & $*$ & & & & \\
\hline G05 & Frequent fainting & $*$ & & & & \\
\hline G06 & Lots of sweat especially cold sweat & $*$ & & & & \\
\hline G07 & $\begin{array}{l}\text { The existence of inherited diabetes } \\
\text { factors }\end{array}$ & $*$ & & & & \\
\hline G08 & Pain and numbness in the legs & & $*$ & & & \\
\hline G09 & Frequent diarrhea & & $*$ & & & \\
\hline G10 & The feeling of touch is less sensitive & & $*$ & & & \\
\hline G11 & Tingling in the legs and arms & & $*$ & & & \\
\hline G12 & Sexual disorders & & $*$ & & & \\
\hline G13 & Loss of ability to see & & & $*$ & & \\
\hline G14 & Blurred vision & & & $*$ & & \\
\hline G15 & Color vision is impaired & & & $*$ & & \\
\hline G16 & Cataracts in the eyes & & & $*$ & & \\
\hline G17 & Loss of appetite & & & & $*$ & \\
\hline G18 & Puffy eyes & & & & $*$ & \\
\hline G19 & Nausea and vomiting & & & & $*$ & \\
\hline G20 & The body feels weak & & & & $*$ & \\
\hline G21 & Urine is difficult & & & & $*$ & \\
\hline G22 & Insomnia (difficulty sleeping) & & & & $*$ & \\
\hline G23 & Itching in the pubic area & & & & & $*$ \\
\hline G24 & Often feel tired & & & & & $*$ \\
\hline G25 & Often feel thirsty & & & & & $*$ \\
\hline G26 & Boils often appear on the body & & & & & $*$ \\
\hline G27 & $\begin{array}{l}\text { Susceptible to infection, whether it's } \\
\text { in the gums, mouth and skin }\end{array}$ & & & & & $*$ \\
\hline G28 & Old wounds heal & & & & & $*$ \\
\hline G29 & $\begin{array}{l}\text { Frequent urination more than five } \\
\text { times a day }\end{array}$ & & & & & $*$ \\
\hline
\end{tabular}

Source : (Mardiana et al., 2019) 
The results from the expert table is illustrated in the decision tree by the forward chaining method as a presented in Figure 2.

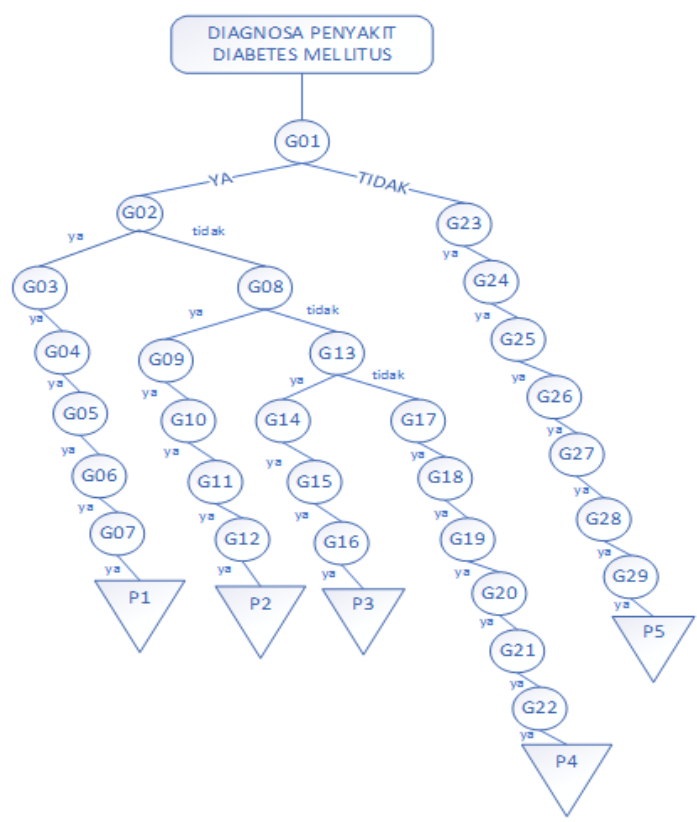

Source : (Mardiana et al., 2019)

Figure 2. Decision Tree to Detect Diabetes Mellitus

The following is the specification of the expert system for diabetes mellitus detection.

1. Visitor Page

The public, medical students or anyone who needs consultation on diabetes information can visit this page. Visitors can see several facilities such as information about diabetes and the management of diabetes mellitus.

2. Administrator Page

On the administrator page, the administrator can add, change, and delete data such as disease data, symptom data and rule data.

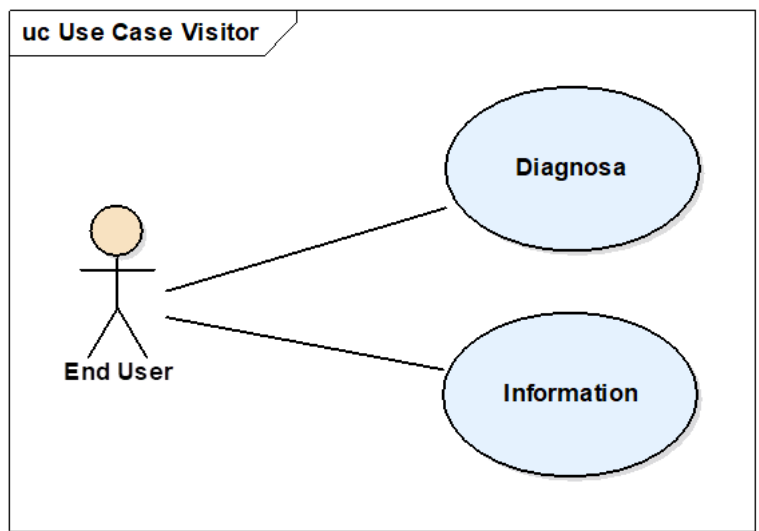

Source : (Mardiana et al., 2019)

Figure 3. Use Case Diagram of The Visitor Page

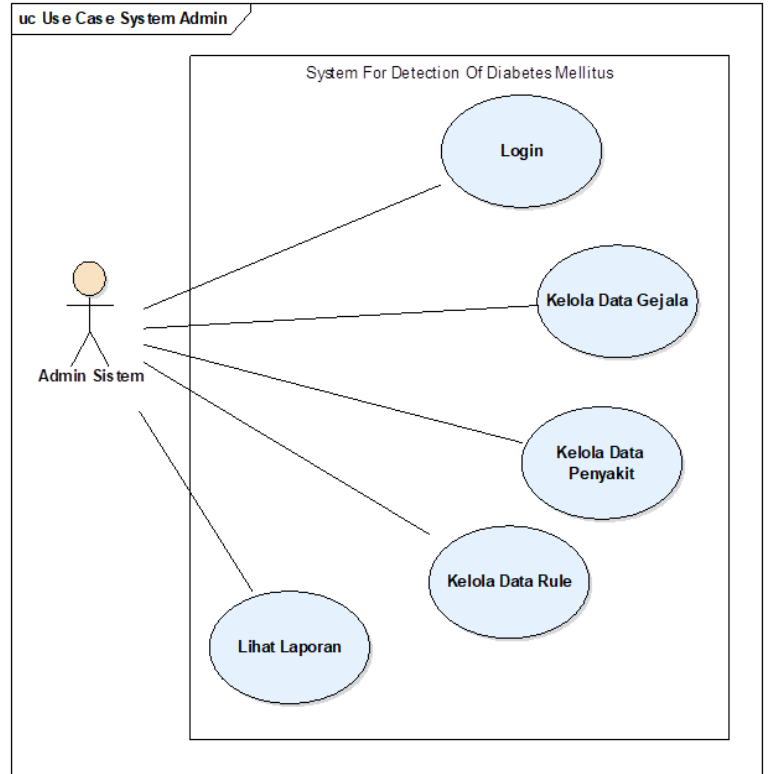

Source : (Mardiana et al., 2019)

Figure 4 Use Case Diagram of The Administrator Page

\section{Software Design}

\section{A. Database Design}

Figure 5 presents the mapping of entities that form a database. The results of the logical record structure transformation resulted in four tables including a symptom table, a disease table, a rules table, and a solution table.

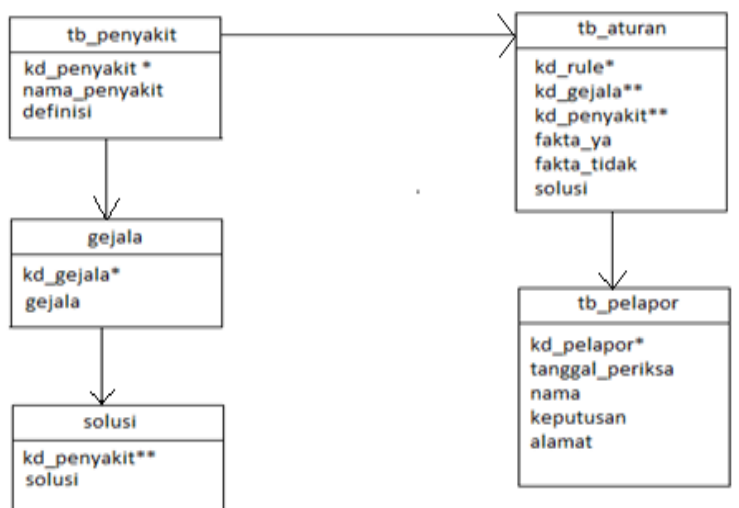

Source : (Mardiana et al., 2019)

Figure 5 LRS of an Expert System to Detect Diabetes Mellitus

\section{B. Functional Design}

The user can access the patient's diagnostic page by selecting the diagnostic menu then answering questions about the symptoms of diabetes then the system displays the type of diabetes and its management solutions. 


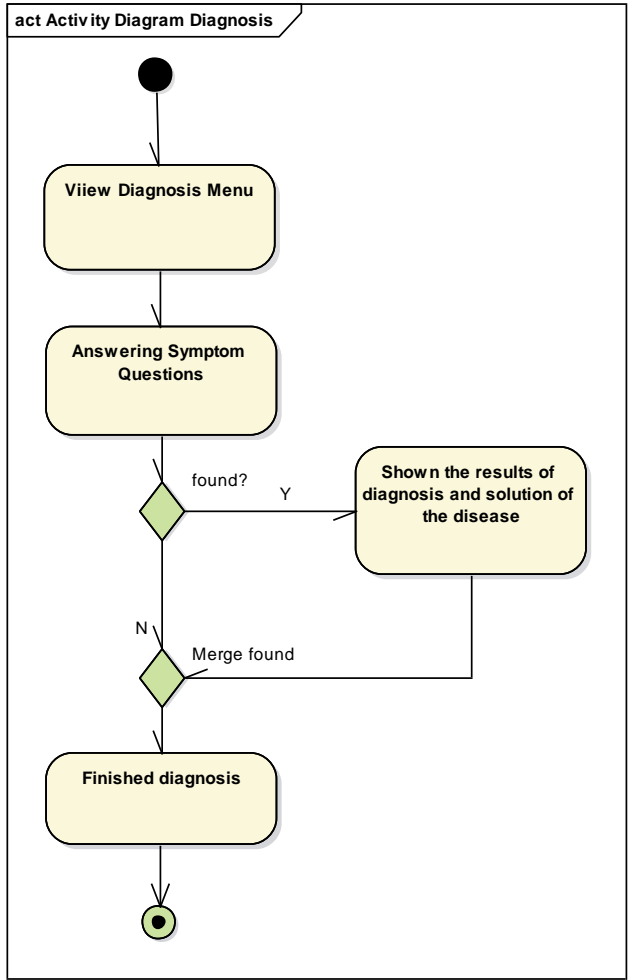

Source : (Mardiana et al., 2019)

Figure 6 Activity Diagram of The Diagnostic Page

The results of implementing the interface design for the application of an expert system to detect diabetes, as follows:

1. When the user enters the diabetes expert system website address, a home screen will appear that contains diabetes.

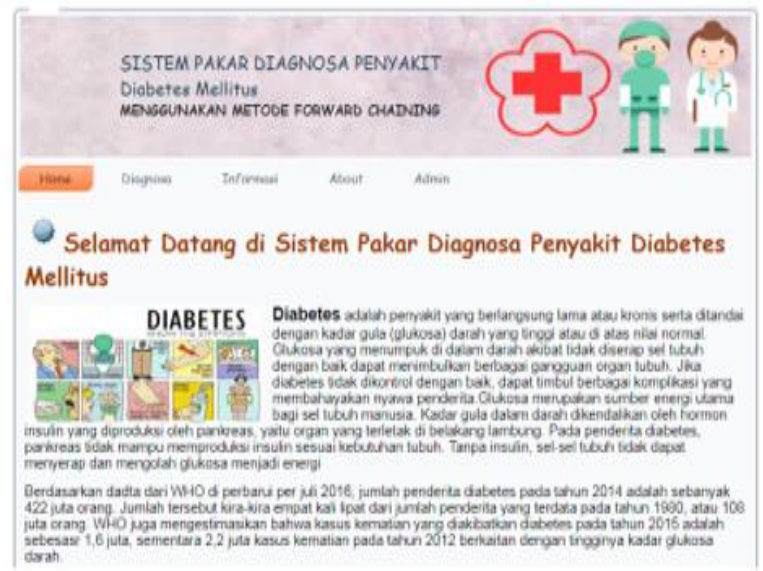

Source : (Mardiana et al., 2019)

Figure 7. Visitor Page

2. When the user chooses the diagnostic menu, questions about symptoms of diabetes will appear and answer the question.

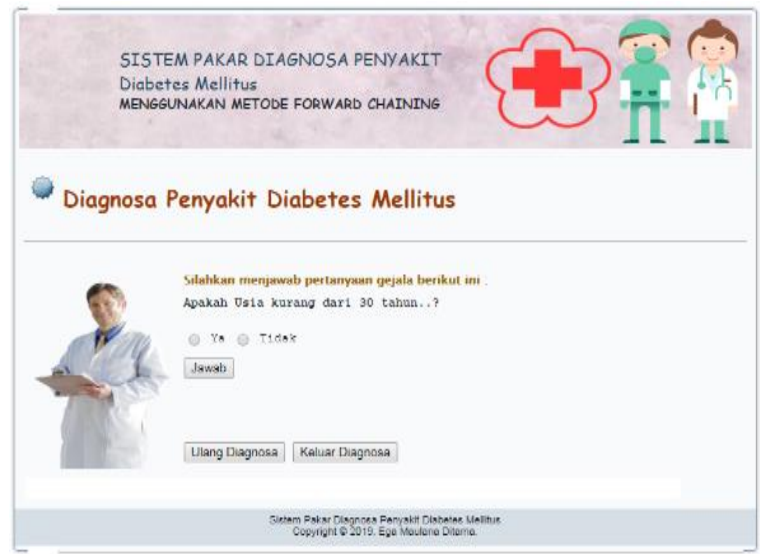

Source : (Mardiana et al., 2019)

Figure 8. Diagnostic Page

3. After the user has finished answering the question the symptoms of eating will appear the results of the diagnosis containing the illness and also the disease solution.

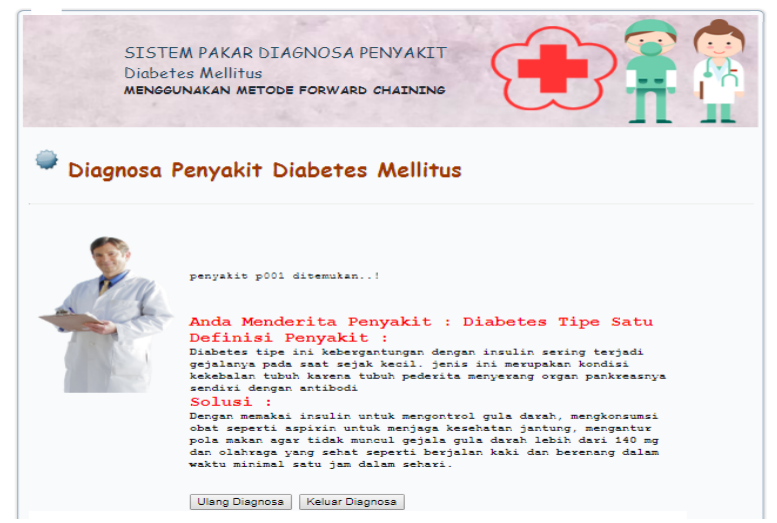

Source : (Mardiana et al., 2019)

Figure 9. Diagnostic Results Page

4. On the login page, the administrator fills in the username and password in order to manage the diabetes mellitus expert system website.
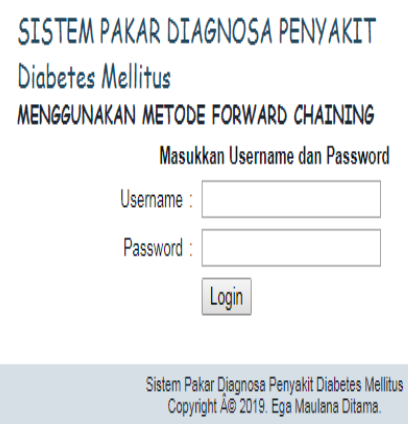

Source : (Mardiana et al., 2019)

Figure 10. Login Page 
5. On the login page, the administrator fills in the username and password to be able to manage the diabetes expert system website.

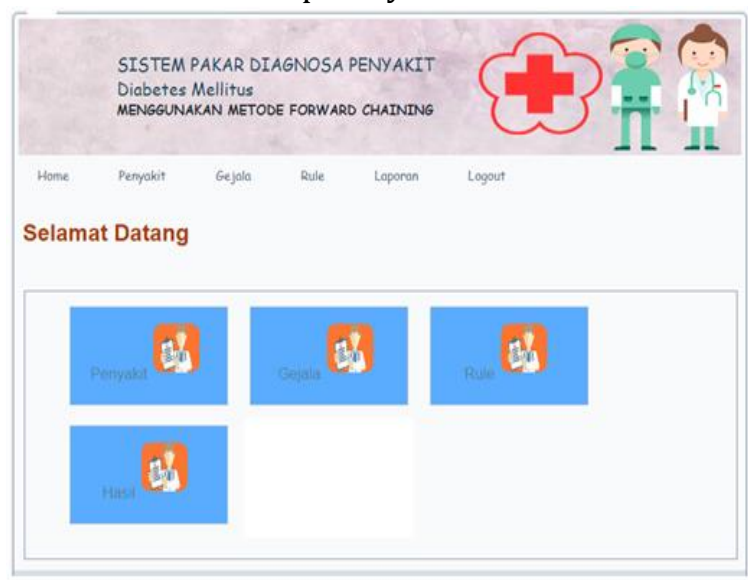

Source : (Mardiana et al., 2019)

Figure 11. Home Page Administrator

6. In the display of disease data, administrators input, modify, and delete disease data and solutions to diseases.

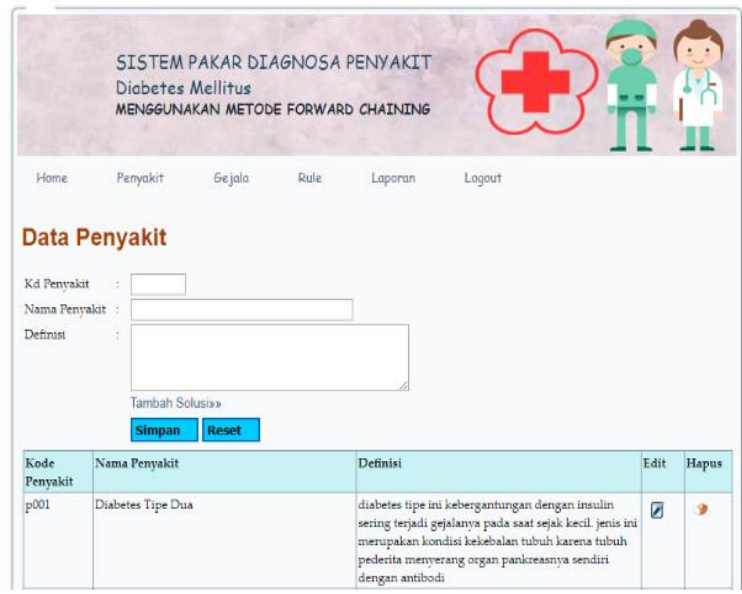

Source : (Mardiana et al., 2019)

Figure 12. Disease Data Page

7. In the symptom data display, the dministrator inputs, changes, and deletes the symptom data.

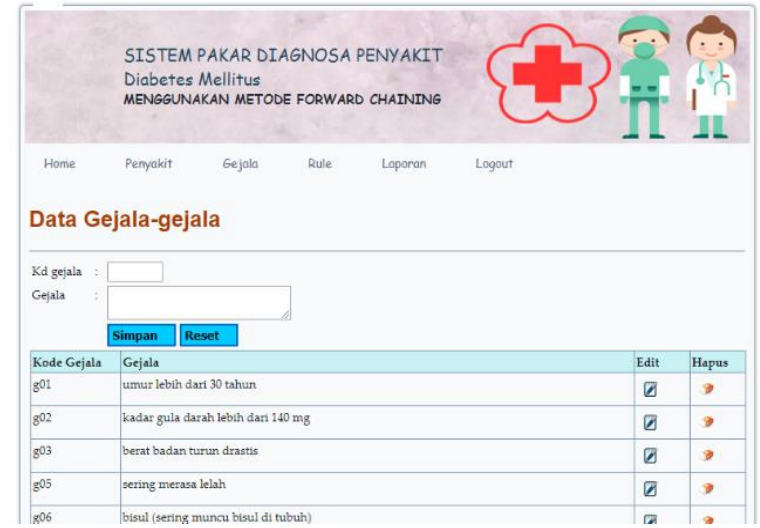

Source : (Mardiana et al., 2019)

Figure 13 Symptom Data Page

8. In the data rule view, the administrator inputs, changes, and deletes data rules.

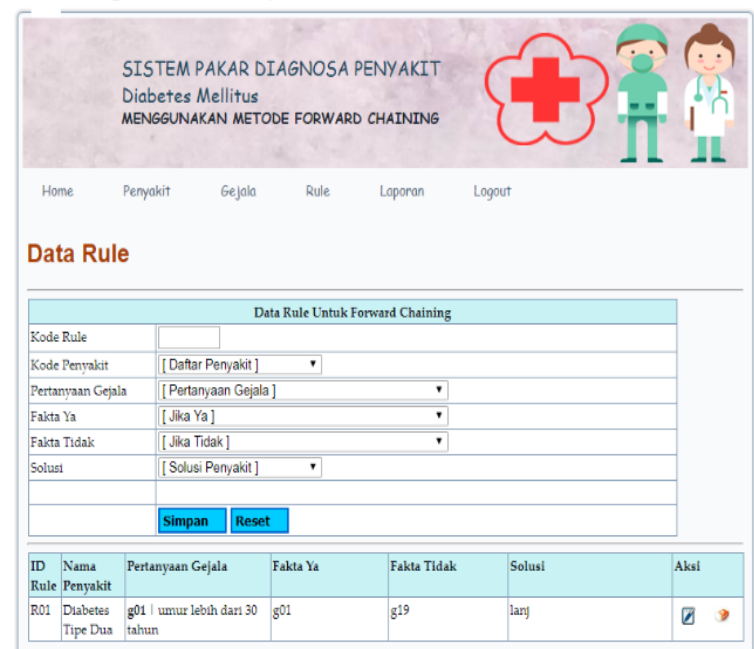

Source : (Mardiana et al., 2019)

Figure 14. Rule Data Page

The system testing phase is the testing phase to test the accuracy of the expert system, namely by making a comparison between the results of the expert system with the truth of the rules.

Table 2. Testing of an Expert Systems For Detecting Diabetes Mellitus

\begin{tabular}{llccc}
\hline Respondents & \multicolumn{1}{c}{ The symptoms } & $\begin{array}{c}\text { Manual Decision } \\
\text { Results }\end{array}$ & Expert system & Information \\
\hline Ragan Bagus & $\begin{array}{l}\text { Age less than 30 years; drink plenty } \\
\text { without weight gain. Frequent } \\
\text { concentration cramps often occur; } \\
\text { disturbed Frequent fainting, lots of } \\
\text { sweat; especially cold sweat; diabetes } \\
\text { inherited }\end{array}$ & $\begin{array}{c}\text { Diabetes Mellitus } \\
\text { Type } 1\end{array}$ & $\begin{array}{c}\text { Diabetes Mellitus } \\
\text { Type 1 }\end{array}$ & Valid \\
& $\begin{array}{l}\text { Age more than 30 years; wounds that } \\
\text { heal for a long time, urinate frequently } \\
\text { more than five times, are susceptible }\end{array}$ & $\begin{array}{c}\text { Diabetes Mellitus } \\
\text { Type 2 }\end{array}$ & Diabetes Mellitus & Type 2 \\
\hline
\end{tabular}




\begin{tabular}{|c|c|c|c|c|}
\hline Respondents & The symptoms & Manual Decision & Expert system & Information \\
\hline & $\begin{array}{l}\text { to infection; whether it's gums, mouth } \\
\text { and skin; often feel thirsty } \\
\text { boils often appear on the body; itching } \\
\text { in the pubic area; often feel tired }\end{array}$ & & & \\
\hline Radito Ibam & $\begin{array}{l}\text { Age less than } 30 \text { years; impaired color } \\
\text { vision; cataracts in the eyes; loss of } \\
\text { ability to see; blurred vision }\end{array}$ & $\begin{array}{c}\text { Diabetic } \\
\text { Retinopathy }\end{array}$ & $\begin{array}{c}\text { Diabetic } \\
\text { Retinopathy }\end{array}$ & Valid \\
\hline Riska Septiana & $\begin{array}{l}\text { Age less than } 30 \text { years; Drink plenty } \\
\text { without weight gain; Cramps often } \\
\text { occur; easily disturbed concentration; } \\
\text { Frequent fainting; lots of sweat } \\
\text { especially cold sweat; diabetes } \\
\text { inherited }\end{array}$ & $\begin{array}{c}\text { Diabetes Mellitus } \\
\text { Type } 1\end{array}$ & $\begin{array}{c}\text { Diabetes Mellitus } \\
\text { Type } 1\end{array}$ & Valid \\
\hline $\begin{array}{l}\text { Aksa } \\
\text { Muhamad }\end{array}$ & $\begin{array}{l}\text { Age less than } 30 \text { years; pain and } \\
\text { numbness in the legs; frequent } \\
\text { diarrhea; sense of touch less sensitive; } \\
\text { tingling in the legs and arms; sexual } \\
\text { disorders }\end{array}$ & $\begin{array}{c}\text { Diabetic } \\
\text { Neuropathy }\end{array}$ & $\begin{array}{c}\text { Diabetic } \\
\text { Neuropathy }\end{array}$ & Valid \\
\hline Joko Susanto & $\begin{array}{l}\text { age over } 30 \text { years; old wounds heal; } \\
\text { frequent urination more than five } \\
\text { times; susceptible to infection, } \\
\text { whether it's gums, mouth and skin; } \\
\text { often feel thirsty boils often appear on } \\
\text { the body; itching in the pubic area; } \\
\text { often feel tired }\end{array}$ & $\begin{array}{c}\text { Diabetes Mellitus } \\
\text { Type } 2\end{array}$ & $\begin{array}{c}\text { Diabetes Mellitus } \\
\text { Type } 2\end{array}$ & Valid \\
\hline Rizki & $\begin{array}{l}\text { Age less than } 30 \text { years; Drink plenty } \\
\text { without weight gain; Cramps often } \\
\text { occur; easily disturbed concentration; } \\
\text { Frequent fainting; lots of sweat } \\
\text { especially cold sweat; diabetes } \\
\text { inherited }\end{array}$ & $\begin{array}{c}\text { Diabetes Mellitus } \\
\text { Type } 1\end{array}$ & $\begin{array}{c}\text { Diabetes Mellitus } \\
\text { Type } 1\end{array}$ & Valid \\
\hline Heri & $\begin{array}{l}\text { Age less than } 30 \text { years; insomnia } \\
\text { (difficulty sleeping); swollen eyes; } \\
\text { nausea and vomiting; body feels weak; } \\
\text { urine is difficult } \\
\text { loss of appetite }\end{array}$ & $\begin{array}{c}\text { Diabetic } \\
\text { Neuropathy }\end{array}$ & $\begin{array}{c}\text { Diabetic } \\
\text { Neuropathy }\end{array}$ & Valid \\
\hline Eva & $\begin{array}{l}\text { Age less than } 30 \text { years; Drink plenty } \\
\text { without weight gain; Cramps often } \\
\text { occur; easily disturbed concentration; } \\
\text { Frequent fainting; lots of sweat } \\
\text { especially cold sweat; diabetes } \\
\text { inherited }\end{array}$ & $\begin{array}{c}\text { Diabetes Mellitus } \\
\text { Type } 1\end{array}$ & $\begin{array}{c}\text { Diabetes Mellitus } \\
\text { Type } 1\end{array}$ & Valid \\
\hline Susila & $\begin{array}{l}\text { Age more than } 30 \text { years; old wounds } \\
\text { heal; frequent urination more than } \\
\text { five times; susceptible to infection, } \\
\text { whether it's gums, mouth and skin; } \\
\text { often feel thirsty } \\
\text { boils often appear on the body; itching } \\
\text { in the pubic area; often feel tired }\end{array}$ & $\begin{array}{c}\text { Diabetes Mellitus } \\
\text { Type } 2\end{array}$ & $\begin{array}{c}\text { Diabetes Mellitus } \\
\text { Type } 2\end{array}$ & Valid \\
\hline
\end{tabular}

We tested the expert system to detect diabetes mellitus and then calculated its accuracy using the following equation:

accuracy $=\frac{\sum \text { test data is correct }}{\sum \text { test data }} \times 100 \%$

Testing accuracy using a sample of 10 respondents. The number of respondent data in accordance with the results of the system is 10 , while the number of respondent data that is not in accordance with the system 0 out of ten sample data. The results of calculating the accuracy of this expert system are as follows:

accuracy $=\frac{10}{10} \times 100 \%=100 \%$ 


\section{CONLUSIONS AND SUGGESTIONS}

In this study we have built an expert system using the method of foward chaining to detect early type one diabetes, type two diabetes, diabetic neuropathy, diabetic retinopathy, and diabetes nephropathy. This expert system has 29 symptoms that indicate five diabetics stored in expert table form. The test results show that the expert system meets the functional requirements and the system performance reaches 100\% accuracy. This expert system helps people in Indonesia to detect diabetes early on accurately and efficiently so as to prevent complications. The next work is to develop an expert system to detect diabetes more broadly and based on mobile applications.

\section{REFERENCES}

Andriyanto, I., \& Santoso, E. (2017). Pemodelan Sistem Pakar Untuk Menentukan Penyakit Diabetes Mellitus Menggunakan Metode Naive Bayes Studi Kasus: Puskesmas Poncokusumo Malang. Jurnal Pengembangan Teknologi Informasi Dan Ilmu Komputer (JPTIIK) Universitas Brawijaya, 2(2), 880-887.

Erawantini, F., Farlinda, S., \& Wulandari, R. A. (2019). Perancangan Aplikasi Penentu Faktor Risiko Diabetes Melitus Tipe 2 Secara Dini Berbasis Web. Jurnal Kesehatan, 5(1), 30-33. kes.v5i1.48

Ginting, B. S., \& Novriyeni, N. (2012). Perancangan Sistem Pakar Untuk Diagnosa Penyakit Diabetes Dengan Metode Forward Chaining. Jurnal Kaputama, 6(1), 33-40. https://doi.org/10.1017/CB097811074153 24.004

Harum, A., Larasati, T., \& Zuraida, R. (2013). Hubungan Diet Serat Tinggi Dengan Kadar Hba1c Pasien Diabetes Melitus Tipe 2 DI RSUD DR.H. Abdul Moeloek Provinsi Lampung. Medical Journal of Lampung
University, 2(4), 79-87.

Inayati, I., \& Qoriani, H. F. (2016). Sistem Pakar Deteksi Penyakit Diabetes Melitus (DM) Dini Berbasis Android. Jurnal Link, 25(2), 10-15.

Mardiana, T., Ditama, E. M., \& Tuslaela, T. (2019). Final Research Report: Expert System for Diagnosing Diabetes Mellitus with the Forward Chaining Method. STMIK Nusa Mandiri.

Ministry of Cooperatives Small and Medium Enterprises. (2015). Building cooperatives and SMEs as National Economic Resilience. 122.

Niswati, Z., Paramita, A., \& Mustika, F. A. (2016). Aplikasi Fuzzy Logic dalam Diagnosa Penyakit Diabetes Mellitus pada PUSKESMAS di Jakarta Timur. Jurnal Nasional Teknologi Dan Sistem Informasi, 2(3), 21-30. https://doi.org/10.25077/teknosi.v2i3.2016. 21-30

Raditiya, B., \& Aditya, M. (2016). Penatalaksanaan Diabetes Melitus Tipe 2 dengan Hiperkolesterolemia pada Seorang Pria Usia 60 Tahun dengan Pendekatan Kedokteran Keluarga Family Medicine Approach Management of 60 Years Old Man with Diabetes. Medula Unila, 5(2), 9-17.

Riadi, A. (2017). Penerapan Metode Certainty Factor Untuk Sistem Pakar Diagnosa Penyakit Diabetes Melitus Pada RSUD Bumi Panua Kabupaten Pohuwato. ILKOM Jurnal Ilmiah, 9(3), 309. https://doi.org/10.33096/ilkom.v9i3.162.30 9-316

Zubaedah, R. (2017). Penerapan Case Based Reasoning Untuk Diagnosis Diabetes Mellitus. Jurnal Ilmiah Mustek Anim Ha, 6(2), 224-235. 